\title{
Zinc and Chromium Load in Road Dust, Suspended Particulate Matter and Foliar Dust Deposits of Anand City, Gujarat
}

\author{
Tanushree Bhattacharya $^{1 *}$, Sukalyan Chakraborty ${ }^{1}$, Dhara Tuteja ${ }^{2}$, Mitul Patel ${ }^{2}$ \\ ${ }^{1}$ Environmental Science and Engineering Group, Birla Institute of Technology, Mesra, Ranchi, India \\ ${ }^{2}$ Department of Environmental Science \& Technology, Institute of Science and Technology for \\ Advanced Studies \& Research, Vallabh Vidyanagar, India \\ Email: *tbhattacharya@bitmesra.ac.in
}

Received May 23, 2013; revised June 26, 2013; accepted July 3, 2013

Copyright (C) 2013 Tanushree Bhattacharya et al. This is an open access article distributed under the Creative Commons Attribution License, which permits unrestricted use, distribution, and reproduction in any medium, provided the original work is properly cited.

\begin{abstract}
Anand, the milk capital of India, is a developing city with increasing vehicles and developmental activities going on at a fast pace. This study attempts to investigate the zinc and chromium concentration in street dust, suspended particulate matter and in foliar dust deposits. Ten sampling locations were selected based on the traffic density on the roads and different anthropogenic activity. Sampling was carried out in the dry months of January to March 2011. The range of $\mathrm{Zn}$ and $\mathrm{Cr}$ was $16.82-108.29 \mathrm{ppm}$ and $118-151.5 \mathrm{ppm}$ in the street dust respectively. $\mathrm{Zn}$ concentration in Suspended particulate matter lies in the range of 12.41 to $86 \mathrm{ppm}$ and $\mathrm{Cr}$ concentration between 75 to $130 \mathrm{ppm}$. The range of $\mathrm{Cr}$ in foliar deposited dust varied from $79.54 \mathrm{ppm}$ to $31 \mathrm{ppm}$. Whereas, for $\mathrm{Zn}$ maximum concentration was in $\mathrm{S}_{10}$ which is $42.34 \mathrm{ppm}$ and minimum was in site $\mathrm{S}_{9}, 23.73 \mathrm{ppm}$. ANOVA single factor showed that at 0.05 level of significance site wise variation of zinc and chromium concentration in SPM, Street dust and foliar deposited dust was not significant signifying similar source of contamination. Which is further strengthened by the good positive correlation found between the $\mathrm{Zn}$ and $\mathrm{Cr}$ concentration of street dust, leaf deposited dust and SPM. The Contamination Factor in the sites where metal concentration was high was 1.24 in $\mathrm{S}_{10}$ and 1.06 in $\mathrm{S}_{5}$ for $\mathrm{Zn}$. For chromium the value of CF was 1.77 in $\mathrm{S}_{10}$ and 1.67 in $\mathrm{S}_{5}$. These values indicate that street dust is moderately contaminated with respect to zinc and chromium.
\end{abstract}

Keywords: Heavy Metal; Street Dust; Contamination; Foliar Deposit; Suspended Particulate Matter

\section{Introduction}

Soils along road environments typically contain high concentrations of heavy metals because of non-point contamination sources, most commonly vehicle exhaust and wear of vehicle parts. To many people, heavy metal pollution is a problem associated with areas of intensive industry [1]. However, roadways and automobiles now are considered to be one of the largest sources of heavy metals. Zinc, copper, and lead are three of the most common heavy metals released from road travel, accounting for at least 90 of the total metals in road run off. Lead concentrations; however, consistently have been decreasing since leaded gasoline was discontinued. Smaller amounts of many other metals, such as nickel and cadmium, chromium are also found in road runoff and exhaust. About half of the zinc and copper contribution to the environ-

"Corresponding author. ment from urbanization is from automobiles. Brakes release copper, while tire wear releases zinc. Motor oil also tends to accumulate metals as it comes into contact with surrounding parts as the engine runs, so oil leaks become another pathway by which metals enter the environment. However, chromium comes from the chrome plating of some of the vehicular parts. Road dust also consists of deposition of vehicle exhausts and industrial exhausts, tire and brake wears, dust from paved roads or potholes, and dust from construction sites [2].

On the road surface, most heavy metals become bound to the surfaces of road dust or other particulates. During precipitation, the bound metals will either become soluble (dissolved) or be swept off the roadway with the dust. In either case, the metals enter the soil or are channeled into a storm drain. Whether in the soil or aquatic environment, metals can be transported by several processes. These processes are governed by the chemical nature of 
metals, soil and sediment particles, and the $\mathrm{pH}$ of the surrounding environment. Dust kicked up by vehicles traveling on roads may make up 33\% of air pollution [3].

Road side soil and vegetation have been shown to be contaminated with various trace elements primarily from automobile exhaust. Metals accumulate in street dust and in the leaves of roadside plants through atmospheric deposition involving sedimentation, impaction and interception [4]. Although there have been a considerable number of studies of heavy metals concentrations in roadside soil and plants, the vast majority of theses have been carried out in developed countries with long histories of Industrialization and extensive use of leaded gasoline and very few studies have been carried out in developing countries such as India where data on the concentration and distribution of metals in street dust are scarce. Therefore, this study examines heavy metal levels in street dust and dust deposited on plants along major traffic roadways in Anand city, Gujarat, India.

\section{Experimental Work}

\subsection{Study Area}

The sampling locations were in Anand city, popularly known as the milk capital of India, situated in the state of Gujarat. It is well known for developing industrial and commercial sectors, educational hubs.

Anand is located in the eastern part of Gujarat: $22^{\circ} 34^{\prime} 0^{\prime \prime} \mathrm{N}$ - 72 $56^{\prime} 0^{\prime \prime} \mathrm{E}$ with an urban population exceeding 2,090,276 inhabitants (Census, 2011). While the predominant wind direction is from the northwest, the wind velocities are usually low. In winter wind speed is $1.9-9.2 \mathrm{~km} \cdot \mathrm{hr}^{-1}$ in a northwest direction and in summer $3.5-10.7 \mathrm{~km} \cdot \mathrm{hr}^{-1}$ in south west direction. The region has a semi arid to arid climate which fosters the transfer of huge amount of suspended particulate matter into the lower levels of the atmosphere in the dry seasons. The vehicular pollution is also growing at an alarming rate with the associated manifestation of increases efflux of toxic heavy metals like $\mathrm{Pb}, \mathrm{Ni}, \mathrm{Zn}$ and $\mathrm{Cu}$ into the environment. The city's industrial belt (Gujarat Industrial Development Corporation) consisting of chemical, dyes, paints, and engineering equipment manufacturing industries also contributes to heavy metal pollution. Samples were collected from ten major roadways of Anand city and the roadways are shown in Figure 1. The detailed description is given in Table 1. Background sample is actually collected from relatively less trafficked rural roadway near Anand city.

\subsection{Sampling}

A total number of 20 road dust samples of each road were collected from 10 major roadways which were the sampling sites. Samples were collected from both the sides of the road i.e. east and west sides. Sampling was

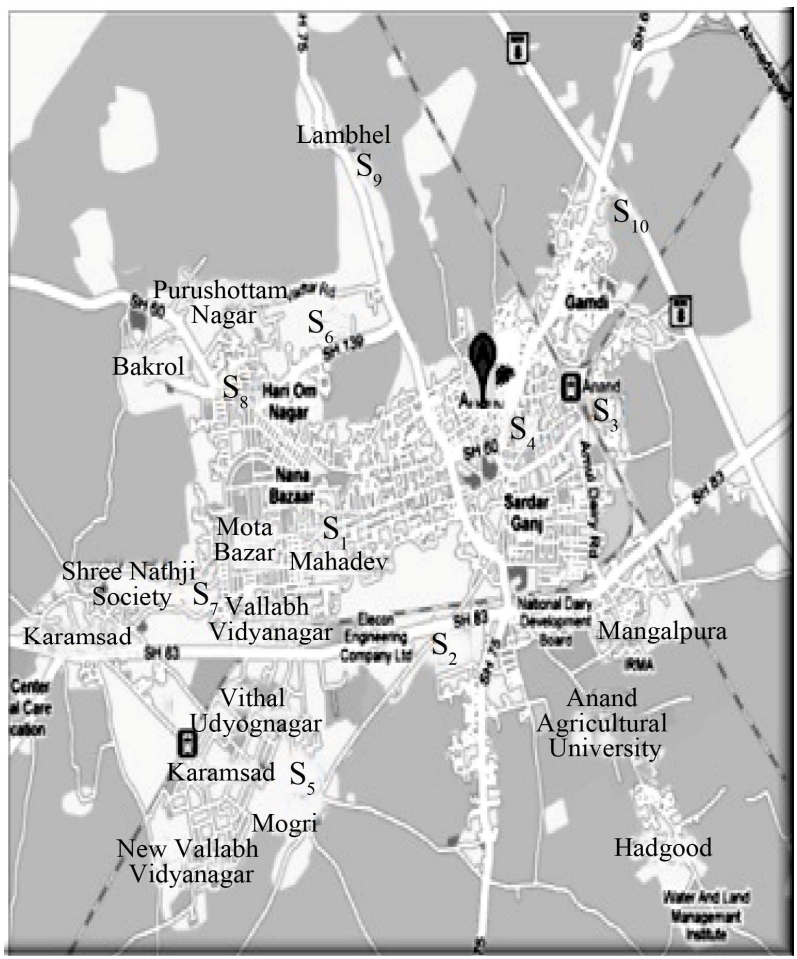

Figure 1. Sampling sites.

carried out in the dry months of January to March 2011. The dust samples were collected from both sides i.e. east and west side of the road using a plastic dust pan and brush. A composite sample was prepared out of it by coning and quartering method. About 100 grams of dust was collected and stored in small self sealing plastic bags. Care was taken to reduce the disturbance to the fine particles to a minimum, as these were readily lost by resuspension. Recently soiled surfaces and areas where car or vehicles were parked or had been parked based on the presence of oil stains were avoided. Any obvious extraneous material, such as cigarette ends or other debris, was not collected with the sample. Between each sampling brush was cleaned thoroughly [5].

For suspended particulate matter collection 6 hour sampling was carried out using a commercially available dust sampler (portable low volume air sampler, Instrumex LVS1) during the peak traffic hours in the morning. Simultaneous measurement of surface meteorological parameters like temperature, relative humidity, wind speed and wind direction were also carried out during the sampling period. The particulate pollutant concentrations were estimated by adopting gravimetric method subsequently.

Leaf dust sample was collected carefully from plant by using soft brush using the methods adopted by. Leaves were collected carefully in zip lock bags. Care was taken to not disturb fine dusts that have settled on the leaves. After that leaves were washed properly in running water 
Table 1. Sampling sites and their description.

\begin{tabular}{|c|c|c|}
\hline Sampling location & Description & Vehicles per hour \\
\hline Anand Vidyanagar Road- $-\mathrm{S}_{1}$ & $\begin{array}{c}\text { Road is } 1.5 \mathrm{kms} \text { long. Both sides of the road are covered by many shopping and commercial } \\
\text { complexes. Heavy traffic prevails on the road throughout the day. }\end{array}$ & $4700 \pm 20$ \\
\hline Janta Borsad Cross Road- $\mathrm{S}_{2}$ & $\begin{array}{l}\text { This road connects Janta Chokdi and Borsad Chokdi covering length of about } 3 \mathrm{kms} \text {. } \\
\text { Mostly, engineering industries are present in this area. }\end{array}$ & $3500 \pm 13$ \\
\hline Anand Railway Station Road- $-\mathrm{S}_{3}$ & $\begin{array}{l}2 \mathrm{kms} \text { long. This road has Railway station on one end and Ganesh Chkokdi on other end which } \\
\text { is a commercial complex. Big commercial complexes, AMUL dairy office, Super markets, bus } \\
\text { station, Police station, Court and other administrative offices are also present along this road. }\end{array}$ & $2900 \pm 16$ \\
\hline New Bus Station Road- $-\mathrm{S}_{4}$ & $1 \mathrm{~km}$ long. Bus station and other commercial complexes are situated beside this road. & $2274 \pm 33$ \\
\hline $\begin{array}{l}\text { Gujarat Industrial Development } \\
\text { Corporation (GIDC) Road- }-\mathrm{S}_{5}\end{array}$ & $\begin{array}{c}\text { The GIDC area is spread over } 3.5 \mathrm{~km}^{2} \text {. Engineering, paints and dye, pesticides, fertilizers, } \\
\text { metal processing industries are situated in this area. }\end{array}$ & $1223 \pm 17$ \\
\hline Vadtal Road- $-\mathrm{S}_{6}$ & $4 \mathrm{~km}$ long. Mainly agricultural fields are present on roadside with some residential areas. & $913 \pm 12$ \\
\hline Iskon Road- $-\mathrm{S}_{7}$ & $1 \mathrm{~km}$ long. Iskon temple, student hostels and residential areas. & $2140 \pm 26$ \\
\hline University Circle Road- $\mathrm{S}_{8}$ & Sardar Patel University, student hostels and residential areas. & $1856 \pm 21$ \\
\hline Lambhel-Sk Road- $\mathrm{S}_{9}$ & $\begin{array}{c}4 \mathrm{kms} \text { long. Connecting road to Nadiad. Few residential complexes, commercial complexes } \\
\text { and agricultural land exists. }\end{array}$ & $1663 \pm 17$ \\
\hline Express Highway $-\mathrm{S}_{10}$ & $\begin{array}{l}\text { Connecting two major cities Ahmedabad-Vadodara. Mainly agricultural field exists beside the } \\
\text { highway with some commercial joints. }\end{array}$ & $2295 \pm 24$ \\
\hline
\end{tabular}

and kept in oven for 2 days for drying. Dried leaves were crushed into fine powder by using mixture grinder available and that leaf powder was stored in small plastic bags for further analysis [6]. Collected dust was stored in small zip lock plastic bags for further analysis. Species selection is done based on dominate species present at that site.

Dust $\mathrm{pH}$ and EC was measured in 1:5 dust to water ratio. They were measured using calibrated meters. Organic carbon is determined by following modified Jackson method [7]. For bringing out heavy metals present in the dust into solution Aqua rigea method was followed. In this 0.5 gm dust sample was taken and then $\mathrm{HNO}_{3}$ : $\mathrm{HCl}$ was added in 3:1 ratio. After that $3 \mathrm{ml}$ perchloric acid was added. In case of dust collected from leaves 5 $\mathrm{ml}$ perchloric acid was added. After the digestion is over remove the flask from hot plate and allow it to cool. For leaf samples $0.5 \mathrm{gm}$ dried leaf sample was digested with $\mathrm{HNO}_{3}: \mathrm{HCl}$ in 9:4 ratio [8].

$\mathrm{Zn}$ and $\mathrm{Cr}$ was analysed by AAS (Perkin Elmeyer model) using an air-acetylene gas mixture using hollow cathode lamp. Statistical analysis viz. correlation and principal component analysis was done is SPSS software version 11.

To assess the extent of contamination of heavy metals in road dust and also provide a measure of the degree of overall contamination along a particular road, contamination factor and pollution load index has been applied. The contamination Factor (CF) parameter is expressed as:

$$
\mathrm{CF}=\mathrm{C}_{\text {metal }} / \mathrm{C}_{\text {background }}
$$

where $\mathrm{CF}$ is the contamination factor, $\mathrm{C}_{\text {metal }}$ is the con- centration of pollutant in sediment $\mathrm{C}_{\text {background }}$ is the background value for the metal and $\mathrm{n}$ is the number of metals.

\section{Results and Discussions}

Table 2 shows that $\mathrm{pH}$ ranges from 6.5 to 8.5. On the road surface, most heavy metals become bound to the surfaces of road dust or other particulates. During precipitation, the bound metals will either become soluble (dissolved) or be swept off the roadway with the dust. In either case, the metals enter the soil or are channeled into a storm drain. Whether in the soil or aquatic environment, metals can be transported by several processes. These processes are governed by the chemical nature of metals, soil and sediment particles, and the $\mathrm{pH}$ of the surrounding environment. $\mathrm{pH}$ tends to be a master variable in this whole process. In acid conditions, there are enough $\mathrm{H}^{+}$ ions in to occupy many of the negatively charged surfaces of clay and organic matter. Little room is left to bind metals, and as a result, more metals remain in the soluble phase [9]. In the present study the $\mathrm{pH}$ varies from acidic to slightly alkaline. Except site 1, in all the other sites the $\mathrm{pH}$ was slightly alkaline. So mobility due to acidic conditions must be limited in the present study condition. According to two-factor ANOVA at 0.05 $\left(F_{0.05 \text { level }}=0.139\right.$ between east and west side and $F_{0.05 \text { level }}$ $=2.29$ within sampling locations) level of significance there is no significant difference between the $\mathrm{pH}$ of street dust of the roadways in all the sites and between both the sides of the road.

Electrical conductivity of roadside dust samples are represented in Table 2. Result lies in the range of 3.02 to 
Table 2. Result of pH, EC and organic carbon of street dust samples of various sites.

\begin{tabular}{ccccccc}
\hline Site & \multicolumn{2}{c}{ Parameters } \\
\cline { 2 - 7 } & \multicolumn{2}{c}{$\mathrm{pH}$} & \multicolumn{2}{c}{ EC } & \multicolumn{2}{c}{ Organic carbon (\%) } \\
\hline & East side & West side & East side & West side & East side & West side \\
$\mathrm{S}_{1}$ & $6.66 \pm 0.22$ & $6.69 \pm 1.99$ & $3.02 \pm 0.29$ & $2.45 \pm 0.45$ & $1.09 \pm 0.26$ & $1.02 \pm 0.67$ \\
$\mathrm{~S}_{2}$ & $7.09 \pm 0.54$ & $8.24 \pm 0.67$ & $1.59 \pm 0.65$ & $1.58 \pm 0.54$ & $1.49 \pm 0.45$ & $1.15 \pm 0.34$ \\
$\mathrm{~S}_{3}$ & $8.3 \pm 0.16$ & $7.81 \pm 0.55$ & $2.45 \pm 0.33$ & $2.972 \pm 0.23$ & $2.24 \pm 0.99$ & $2.11 \pm 0.45$ \\
$\mathrm{~S}_{4}$ & $7.72 \pm 1.04$ & $7.78 \pm 1.39$ & $1.57 \pm 0.78$ & $1.948 \pm 0.68$ & $1.02 \pm 0.80$ & $0.85 \pm 0.52$ \\
$\mathrm{~S}_{5}$ & $7.13 \pm 1.43$ & $7.16 \pm 0.32$ & $2.75 \pm 0.47$ & $2.77 \pm 0.50$ & $0.81 \pm 0.03$ & $0.64 \pm 0.67$ \\
$\mathrm{~S}_{6}$ & $7.06 \pm 0.89$ & $7.17 \pm 0.76$ & $0.84 \pm 0.33$ & $0.90 \pm 0.30$ & $1.17 \pm 0.87$ & $1.02 \pm 0.11$ \\
$\mathrm{~S}_{7}$ & $7.9 \pm 0.55$ & $7.66 \pm 0.65$ & $0.90 \pm 0.21$ & $1.09 \pm 0.43$ & $1.54 \pm 0.34$ & $1.92 \pm 0.45$ \\
$\mathrm{~S}_{8}$ & $7.84 \pm 1.78$ & $8.01 \pm 1.21$ & $0.89 \pm 0.56$ & $1.09 \pm 0.67$ & $1.13 \pm 0.78$ & $1.39 \pm 0.48$ \\
$\mathrm{~S}_{9}$ & $7.47 \pm 0.99$ & $7.49 \pm 0.58$ & $1.54 \pm 0.49$ & $1.56 \pm 0.39$ & $0.94 \pm 0.15$ & $0.85 \pm 0.23$ \\
$\mathrm{~S}_{10}$ & $7.0 \pm 0.10$ & $7.5 \pm 0.27$ & $0.88 \pm 0.49$ & $0.90 \pm 0.54$ & $0.75 \pm 0.07$ & $0.54 \pm 0.16$ \\
Background soil & $7.83 \pm 0.54$ & $6.83 \pm 0.52$ & $0.709 \pm 0.33$ & $1.038 \pm 0.41$ & $1.17 \pm 0.12$ & $0.96 \pm 0.32$ \\
\hline
\end{tabular}

0.5 milli $\mathrm{S}$. The decreasing order of EC in street dust samples of all the sites is $\mathrm{S}_{1}>\mathrm{S}_{5}>\mathrm{S}_{3}>\mathrm{S}_{4}>\mathrm{S}_{2}>\mathrm{S}_{9}>\mathrm{S}_{7}$ $>\mathrm{S}_{8}>\mathrm{S}_{10}>\mathrm{S}_{1}$. ANOVA shows that at 0.05 level of significance there is no significant difference in the data of Electrical Conductivity of the street dust samples of east and west side of the road, but significant variation lies within the ten sampling locations $\left(F_{0.05}\right.$ level $=1.49$ between east and west side and $F_{0.05 \text { level }}=30.86$ within sampling locations). Electrical conductivity gives a rough idea about the dissolved metal and salt status. Variations within the sampling locations were may be due to this.

Table 2 also shows the percentage organic carbon in the street dust samples. $\mathrm{S}_{3}$ which is Railway station Amul dairy road shows maximum reading as the entire road have good vegetation cover on the both sides of the road and Anand's biggest vegetable market is also present on this road. On the other hand $\mathrm{S}_{10}$ which is Expressway shows the minimum reading as least vegetation us present on the site. The decreasing order of in street dust samples of all the sites is $\mathrm{S}_{3}>\mathrm{S}_{7}>\mathrm{S}_{2}>\mathrm{S}_{8}>\mathrm{S}_{6}>\mathrm{S}_{1}>\mathrm{S}_{4}$ $>\mathrm{S}_{9}>\mathrm{S}_{8}>\mathrm{S}_{10}$. ANOVA shows that at 0.05 level of significance there is no significant difference in the data of Organic Carbon of the street dust samples of east and Westside of the roads where as sitewise variation of ten different sites was significant $\left(F_{0.05 \text { level }}=1.62\right.$ between east and west side and $F_{0.05 \text { level }}=17.58$ within sampling locations). Organic matter content can bind metals and reduces mobility of metal. So it can be inferred that dust samples having more organic carbon will have less mobile metal fraction. However detailed solid phase speciation is needed to confirm this.

\subsection{Zinc in and Chromium in Street Dust}

Figure 2 shows $\mathrm{Zn}$ content in the street dust. Among the different sites studied, $\mathrm{Zn}$ content is found highest in $\mathrm{S}_{10}$ (108.29 ppm) which is the Express highway followed by $\mathrm{S}_{5}(92.19 \mathrm{ppm})$ which is the GIDC area. The range of $\mathrm{Zn}$ was $16.82-108.29 \mathrm{ppm}$ in the street dust. The decreasing order of $\mathrm{Zn}$ content in street dust is in the following order $\mathrm{S}_{10}>\mathrm{S}_{5}>\mathrm{S}_{2}>\mathrm{S}_{4}>\mathrm{S}_{1}>\mathrm{S}_{3}>\mathrm{S}_{7}>\mathrm{S}_{6}>\mathrm{S}_{9}>\mathrm{S}_{8}$. Major sources of $\mathrm{Zn}$ are Tire wear, Motor oil, Grease, Brake emissions, Corrosion of galvanized parts [10-12]. At Express highway $\left(S_{10}\right)$ vegetation cover was less so microclimatic difference due to shading effect of trees was negligible. So, road temperature was very high which leads to high amount of tire wear of vehicles passing form the highway. GIDC $\left(\mathrm{S}_{5}\right)$ area has industrial sources

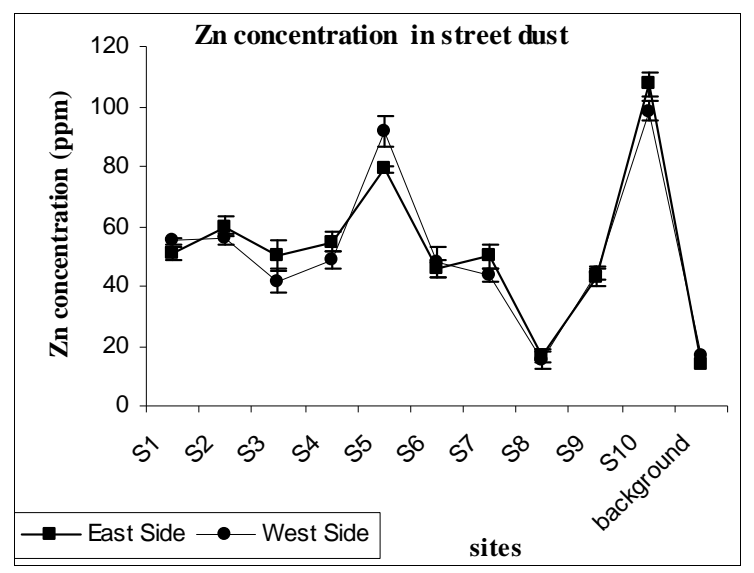

Figure 2. Zn concentrations in street dust. 
of $\mathrm{Zn}$ along with the above sources, as many electroplating industries and galvanization industries are present here. Standard error bars in the Figure shows the variation in the sampling. The background concentration of $\mathrm{Zn}$ is around $15 \mathrm{ppm}$. Less trafficked area like University circle road, Vadtal, Lambhel Sk road shows less Zn concentration. The maximum acceptable limit for $\mathrm{Zn}$ in soil is $300 \mu \mathrm{g} / \mathrm{g}$, however there is no such limit for street dust. None of the sites in our city exceeds this limit [13]. Especially our data of $\mathrm{Zn}$ matches with many reported studies [14-16].

Figure 3 shows $\mathrm{Cr}$ content in the street dust of different sites. Among the different sites studied $\mathrm{Cr}$ content was found highest in $\mathrm{S}_{5}(151.50 \mathrm{ppm})$ which is the GIDC area followed by $S_{10}(146.25 \mathrm{ppm})$ which is the Express highway. The range of $\mathrm{Cr}$ was 118 - $151.5 \mathrm{ppm}$. Major sources of $\mathrm{Cr}$ are Air conditioning coolants, Engine parts, Brake emissions, wear and tear of chrome plated vehicular parts, yellow paints on the roads used for marking and metal industries [17]. GIDC has industrial sources of $\mathrm{Cr}$ along with the vehicular emissions. At express highway $\mathrm{Cr}$ content is high because of high number of vehicles. The decreasing order of $\mathrm{Cr}$ content in street dust is in the following order $\mathrm{S}_{5}>\mathrm{S}_{10}>\mathrm{S}_{1}>\mathrm{S}_{2}>\mathrm{S}_{3}>\mathrm{S}_{4}>\mathrm{S}_{8}>\mathrm{S}_{7}>$ $\mathrm{S}_{6}>\mathrm{S}_{9}$. The background concentration of $\mathrm{Cr}$ is around $110 \mathrm{ppm}$, which is high. So, some geogenic inputs can also be one of the causes of elevated $\mathrm{Cr}$ concentration. ANOVA single factor showed that at 0.05 level of significance site wise variation of zinc and chromium concentration in street dust was not significant $(F=0.46)$. This indicates that may be origin or source of these two metals are same which may be anthropogenic vehicular emissions. Less trafficked and rural areas like University circle road, Vdatal, Lambhel Sk road, Iskon road shows less $\mathrm{Cr}$ concentration. $\mathrm{Cr}$ content in the street dust is in accordance with globally reported studies [18-21].

Comparison with different reported studies is shown in Table 3.

\subsection{Zinc and Chromium in Suspended Particulate Matter (SPM)}

Figure 4 shows that $\mathrm{Zn}$ concentration in SPM lies in the range of 12.41 to $86 \mathrm{ppm}$. High $\mathrm{Zn}$ concentration is found in $S_{10}(85.75 \mathrm{ppm})$ followed by $\mathrm{S}_{5}(61.54 \mathrm{ppm})$ and $\mathrm{S}_{2}(49.16 \mathrm{ppm})$ in SPM. The sources of Zn in SPM are similar as described in street dust sources. The data was also represented in nano $\mathrm{gm} / \mathrm{m}^{3}$ i.e. nano gm of $\mathrm{Zn}$ present in $\mathrm{SPM} / \mathrm{m}^{3}$ volume of air. The decreasing order of $\mathrm{Zn}$ content in SPM is in the following order $\mathrm{S}_{10}>\mathrm{S}_{5}>\mathrm{S}_{2}$ $>S_{1}>S_{7}>S_{3}>S_{4}>S_{6}>S_{9}>S_{8}$. The results were compared with several Global and Indian studies and it was found that the $\mathrm{Zn}$ content is in accordance with some global and Indian studies which are compared [22]. Figure 5 shows the Cr concentration in SPM in Anand
Table 3. Comparison with different reported studies.

\begin{tabular}{|c|c|c|c|}
\hline Study area & Zn (ppm) & Cr (ppm) & Reference \\
\hline $\begin{array}{c}\text { Dhaka, } \\
\text { Bangladesh }\end{array}$ & 169 & $77-160$ & $\begin{array}{l}\text { Ahmed et al., } \\
2006 \text { [1] }\end{array}$ \\
\hline Calcutta, India & 159 & 54 & $\begin{array}{c}\text { Chaterjee et al., } \\
1999 \text { [4] }\end{array}$ \\
\hline Delhi, India & $120-380$ & $100-1350$ & $\begin{array}{l}\text { Banerjee et al., } \\
\quad 2003[5]\end{array}$ \\
\hline $\begin{array}{l}\text { Islamabad } \\
\text { Pakistan }\end{array}$ & 116 & - & $\begin{array}{c}\text { Faiz et al., } 2009 \\
{[8]}\end{array}$ \\
\hline $\begin{array}{l}\text { Islam Sahar, } \\
\text { Tehran, Iran }\end{array}$ & $78.2-162.25$ & $60.3-117.2$ & $\begin{array}{l}\text { Yazdi et al., } \\
2009 \text { [14] }\end{array}$ \\
\hline Kano, Nigeria & $167.53-270.13$ & $1.75-62.53$ & $\begin{array}{l}\text { Alhassan et al., } \\
\quad 2012 \text { [15] }\end{array}$ \\
\hline $\begin{array}{c}\text { Adamawa State, } \\
\text { Nigeria }\end{array}$ & $102.22-705.8$ & $1.22-5.40$ & $\begin{array}{c}\text { Shinggu et al., } \\
2007 \text { [16] }\end{array}$ \\
\hline Xian, China & 421 & 167 & $\underset{[17]}{\text { Yongming et al., }}$ \\
\hline $\begin{array}{l}\text { Ketu-South, } \\
\text { Ghana }\end{array}$ & $18.20-406.5$ & $284.0-4106.0$ & $\begin{array}{l}\text { Addo et al., } \\
2012,[18]\end{array}$ \\
\hline Yazgat, Turkey & $226-1852$ & - & $\begin{array}{c}\text { Divrikli et al, } \\
2003 \text { [19] }\end{array}$ \\
\hline Brimingham, UK & 534 & - & $\begin{array}{c}\text { Charlesworth et } \\
\text { al., } 2003 \text { [20] }\end{array}$ \\
\hline $\begin{array}{c}\text { Zagazig City, } \\
\text { Egypt }\end{array}$ & $163.83-282.51$ & $59.17-78.86$ & $\begin{array}{c}\text { ElShayep et al., } \\
2001[21]\end{array}$ \\
\hline $\begin{array}{l}\text { Anand City, } \\
\text { Gujarat, India }\end{array}$ & $16.82-108.29$ & $118-151.5$ & Present study \\
\hline
\end{tabular}

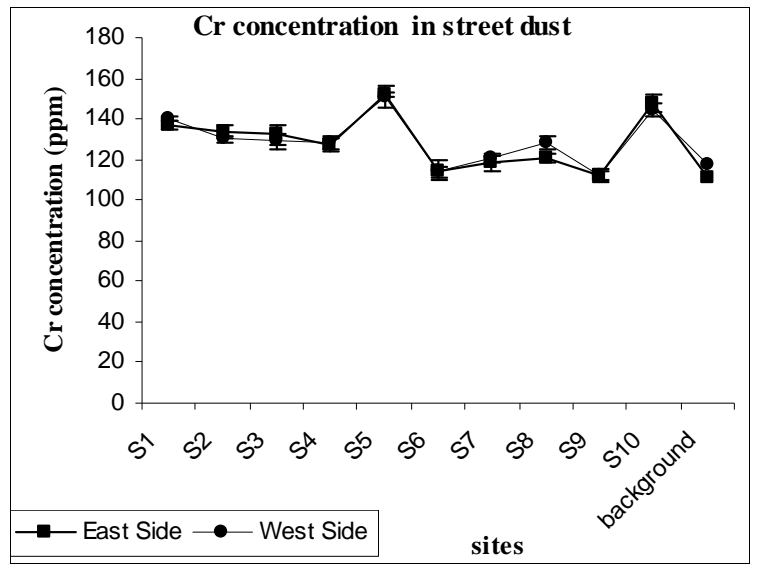

Figure 3. Cr concentrations in street dust

city ranges between 75 to $130 \mathrm{ppm}$. High $\mathrm{Cr}$ content is found in $S_{5}$ followed by $S_{9}$ and then $S_{1}$ sites which is GIDC area, Sk lambhel road, and Anand Vidyanagar road respectively. The sources of $\mathrm{Cr}$ are similar as described for street dust sources. The data was represented in nano $\mathrm{gm} / \mathrm{m}^{3}$ i.e. nano gm of $\mathrm{Cr} / \mathrm{m}^{3}$ volume of air The decreasing order of $\mathrm{Cr}$ content in SPM is in the following order $\mathrm{S}_{5}>\mathrm{S}_{9}>\mathrm{S}_{2}>\mathrm{S}_{1}>\mathrm{S}_{4}>\mathrm{S}_{6}>\mathrm{S}_{10}>\mathrm{S}_{3}>\mathrm{S}_{7}>\mathrm{S}_{8}$. ANOVA single factor showed that at 0.05 level of sig- 


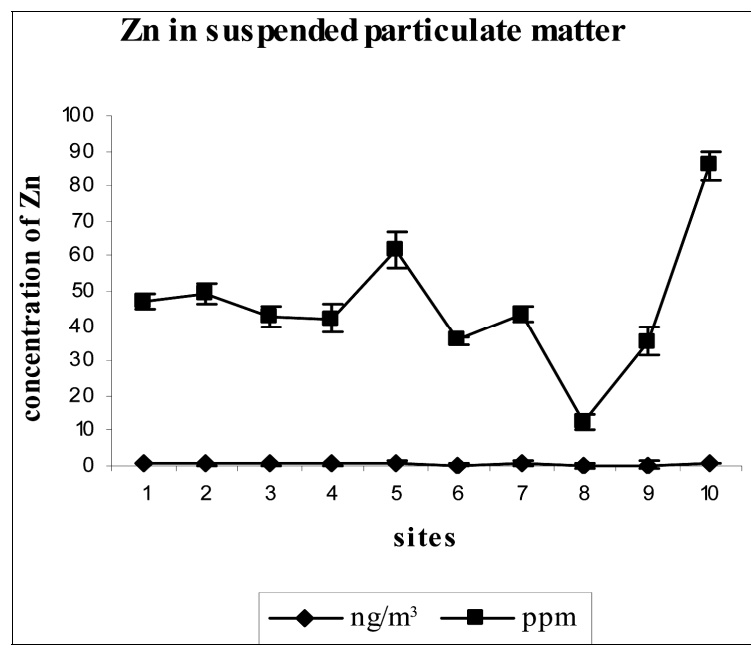

Figure 4. Cr concentrations in street dust.

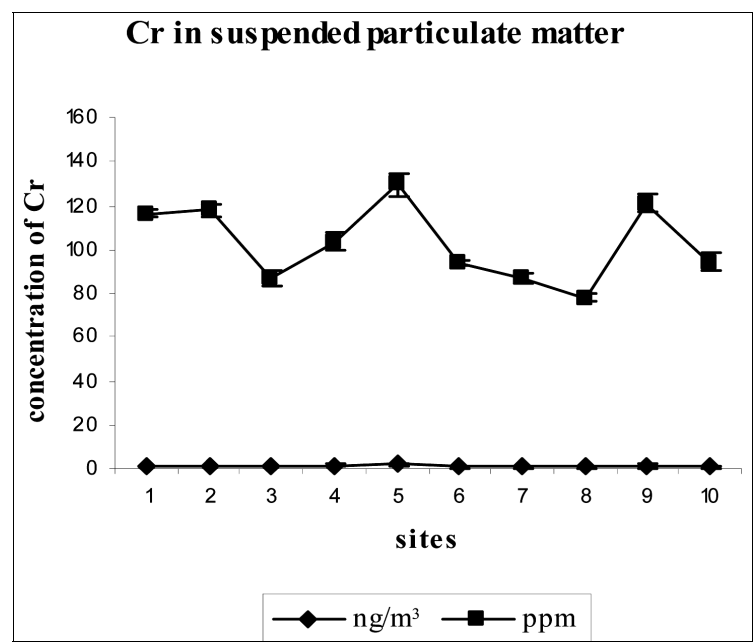

Figure 5. Cr concentration in suspended particulate matter in $\mathbf{n g} / \mathrm{m}^{3}$ and in $\mathbf{p p m}$.

nificance site wise variation of zinc and chromium concentration in SPM was not significant $(F=0.23)$, signifying same origin of these two metals in SPM.

$\mathrm{PM}_{10}$ was sampled for the zinc and chromium load calculation in the suspended particulate matter. However, further analysis of $\mathrm{PM}_{2.5}$ should be done to predict the health impacts. $\mathrm{Zn}$ and $\mathrm{Cr}$ content in SPM is less compared to metropolitan cities of India like Delhi (185 1320 ppm Zn; 112 - 131 ppm Cr), Calcutta (750 - 5160 ppm Zn, 130 - 197 ppm), and Madras (2720 - 3930 ppm Zn, 170 - 280 ppm Cr), Cochin (2350 - 4925 ppm Zn, 175 - 285 ppm Cr) [23].

\subsection{Heavy Metal Concentration of Dust Deposited on Leaf}

To estimate the foliar deposition and the effect of atmospheric dust fall out on the leaf surface metal concentration were analyzed on the leaf deposited dust and the results found were given in Table 4. Site wise the decreasing order of $\mathrm{Cr}$ concentration in leaf deposited dust was as follows. $\mathrm{S}_{5}>\mathrm{S}_{10}>\mathrm{S}_{2}>\mathrm{S}_{1}>\mathrm{S}_{4}>\mathrm{S}_{6}>\mathrm{S}_{3}>\mathrm{S}_{8}>$ $\mathrm{S}_{7}>\mathrm{S}_{9}$. However, ANOVA single factor showed that at 0.05 level of significance site wise variation of zinc and chromium concentration in deposited leaf was not significant $(F=1.24)$ indicating same source of metals. The range of $\mathrm{Cr}$ concentration varied from $79.54 \mathrm{ppm}$ to 31 ppm. It was found that maximum $\mathrm{Zn}$ concentration was in $\mathrm{S}_{10}$ which was $42.34 \mathrm{ppm}$ and minimum in site $\mathrm{S}_{9}$, $23.73 \mathrm{ppm}$. Sources of $\mathrm{Cr}$ in the deposited dust may be due to natural weathering and wind deflation or anthropogenic emission from the industries and vehicles. The trend of $\mathrm{Cr}$ concentration in leaf deposited dust was similar to the trend found in street dust. Foliar deposition of dust depends largely on meteorological conditions and dust capturing capacity of the leaves of the plants growing beside the roadways. Minimum wind speed during sampling period was $1.6 \mathrm{~km} / \mathrm{hr}(0.44 \mathrm{~m} / \mathrm{s})$ and maximum wind speed was $4.4 \mathrm{~km} / \mathrm{hr}(1.2 \mathrm{~m} / \mathrm{s})$. When data of wind speed were compared with Beaufort scale it was found that wind condition was light and calm throughout the sampling period. Direction of wind was from south mainly. No precipitation was found at the time of sampling so washing of street and leaves did not occur, which gives actual results. All these meteorological parameters favored the deposition of dusts on leaf surface and street.

\subsection{Correlation Analysis}

Pearson's correlation coefficients for metal elements in street dusts, deposited dust on leaf and in air in Anand city are summarized in Table $\mathbf{5}$. Inter-element relationship and inter-segment relationship provides interesting information on the sources and pathways of metals. Inter element relationship between leaf deposited dust was

Table 4. Metal concentrations in leaf deposited dust.

\begin{tabular}{ccc}
\hline Sampling sites & $\mathrm{Cr}$ & $\mathrm{Zn}$ \\
\hline $\mathrm{S}_{1}$ & $52.94 \pm 3.04$ & $40.46 \pm 2.09$ \\
$\mathrm{~S}_{2}$ & $58.94 \pm 1.12$ & $32.26 \pm 1.03$ \\
$\mathrm{~S}_{3}$ & $41.54 \pm 2.13$ & $28.82 \pm 2.04$ \\
$\mathrm{~S}_{4}$ & $49.35 \pm 3.04$ & $24.54 \pm 1.04$ \\
$\mathrm{~S}_{5}$ & $79.54 \pm 4.04$ & $43.90 \pm 4.22$ \\
$\mathrm{~S}_{6}$ & $42.86 \pm 2.01$ & $27.01 \pm 2.11$ \\
$\mathrm{~S}_{7}$ & $34.09 \pm 1.32$ & $23.90 \pm 3.03$ \\
$\mathrm{~S}_{8}$ & $39.01 \pm 0.56$ & $25.37 \pm 1.11$ \\
$\mathrm{~S}_{9}$ & $31.00 \pm 1.82$ & $23.73 \pm 2.05$ \\
$\mathrm{~S}_{10}$ & $60.21 \pm 2.54$ & $42.34 \pm 2.14$ \\
\hline
\end{tabular}


Table 5. Correlation analysis.

\begin{tabular}{|c|c|c|c|c|c|c|c|c|c|}
\hline & $\begin{array}{c}\text { Cr in Street } \\
\text { dust }\end{array}$ & $\begin{array}{l}\mathrm{Zn} \text { in street } \\
\text { dust }\end{array}$ & $\begin{array}{l}\mathrm{Zn} \text { in deposited } \\
\text { dust on leaf }\end{array}$ & $\begin{array}{l}\text { Cr in deposited } \\
\text { dust on leaf }\end{array}$ & $\mathrm{Cr}$ in $\mathrm{SPM}$ & $\mathrm{Zn}$ in SPM & $\mathrm{pH}$ & EC & $\mathrm{OC}$ \\
\hline $\mathrm{Cr}$ in street dust & 1 & & & & & & & & \\
\hline $\mathrm{Zn}$ in street dust & 0.433 & 1.000 & & & & & & & \\
\hline $\mathrm{Zn}$ in deposited dust on leaf & 0.483 & -0.388 & 1.000 & & & & & & \\
\hline $\mathrm{Cr}$ in deposited dust on leaf & 0.569 & -0.187 & $0.855^{*}$ & 1.000 & & & & & \\
\hline $\mathrm{Cr}$ in SPM & $0.997^{*}$ & 0.443 & 0.465 & 0.559 & 1.000 & & & & \\
\hline $\mathrm{Zn}$ in SPM & 0.352 & -0.387 & 0.749 & 0.651 & 0.331 & 1.000 & & & \\
\hline $\mathrm{pH}$ & -0.608 & 0.101 & -0.719 & -0.566 & -0.575 & -0.500 & 1 & & \\
\hline $\mathrm{EC}$ & 0.606 & 0.261 & 0.514 & 0.457 & 0.589 & 0.152 & -0.285 & 1.000 & \\
\hline $\mathrm{OC}$ & -0.394 & -0.074 & -0.375 & -0.377 & -0.415 & -0.284 & 0.535 & 0.137 & 1 \\
\hline
\end{tabular}

*Signifies strong significant correlation, underlined values signifies moderate correlation.

found positive in all the cases. This can be interpreted as; if any of the two metals concentration increases other will also increase. This gives an idea that both may have common origin such as industrial, vehicular or natural origin. Good correlation exists between the $\mathrm{Zn}$ and $\mathrm{Cr}$ concentration of street dust, leaf deposited dust and SPM. Furthermore, strong positive correlation exist between leaf deposited $\mathrm{Zn}$ and chromium. This fact also depict that the sources are common for these metals in street dust, air and atmospheric fallout and in leaf deposition. The metal concentrations do not correlate significantly with $\mathrm{pH}$, organic carbon and EC. Owing to the narrow range of these parameters in the samples, so these parameters have limited importance on metal distribution.

\subsection{Contamination Factor}

As per the formula of contamination factor (CF) discussed in experimental section, the $\mathrm{CF}$ in the sites where metal concentration was high was 1.24 in $\mathrm{S}_{10}$ and 1.06 in $\mathrm{S}_{5}$ for $\mathrm{Zn}$. For chromium the value of CF was 1.77 in $\mathrm{S}_{10}$ and 1.67 in $\mathrm{S}_{5}$. The $\mathrm{CF}$ reflects the metal enrichment in the dust. The geochemical background values in continental crust averages of the trace metals under consideration are taken as $95 \mathrm{ppm}$ for $\mathrm{Zn}$ and $90 \mathrm{ppm}$ for $\mathrm{Cr}$ [24]. The CF was classified into four groups. Where the contamination factor $\mathrm{CF}<1$ refers to low contamination; $1 \leq$ $\mathrm{CF}<3$ means moderate contamination; $3 \leq \mathrm{CF} \leq 6$ indicates considerable contamination and $\mathrm{CF}>6$ indicates very high contamination. So the results, indicates that street dust is moderately contaminated with respect to $\mathrm{Zn}$ and chromium. The sites with relatively less traffic and the rural background area had CF less than 1.

Zinc is essential at very low concentrations for life because they have important roles in metabolic processes taking place in living cells. The presence of these metals ions at elevated levels in the environment is often toxic to living organisms. This involves blocking essential functional groups, displacing essential metal ions, or modifying the active confirmation of biological molecules resulting in the inhibition of a variety of metabolic as well as enzyme activities in living organisms. The metal toxicity has a direct effect on various physiological and biochemical processes such as photosynthesis, chlorophyll content and reduction in plant growth. Water soluble zinc that is located in soils can contaminate groundwater. Zinc ions may also increase the acidity of water. The metal that enters the bodies of plants and animals is able to bio-magnify up the food chain. Chromium(III) is an essential element at trace level whereas Chromium(VI) is mainly toxic to living organisms. High concentrations of chromium can cause respiratory problems in animals, a lower ability to fight disease, birth defects, infertility and tumor formation [25].

\section{Conclusion}

Anand city has developed in a rapid pace in past few years. The number of vehicles also increased in past few years at an alarming rate. Many commercial areas and construction activities along with industrial activities have also taken place within a short time span. So, heavy metal pollution due to anthropogenic inputs is most likely increasing with the developmental activities. Zinc and Chromium concentration were moderately high in the street dust. Contamination factor in the industrial area and highly trafficked area was also found moderately high. The heavy metal contaminations in street dust show a considerable decrease from place of high traffic activities to a place of low traffic activities. SPM and foliar deposited dust also showed similar trends as street dust. From street dust the bioavailable and soluble portion of 
zinc and chromium can find its way to groundwater and surface water bodies and can enter food chain. If they are present in suspended dust fraction $\mathrm{PM}_{2.5}$ then it can be inhaled too. Finally, results obtained from this research work would now provide significant reference value for future studies.

\section{REFERENCES}

[1] F. Ahmed and H. Ishiga, "Trace Metal Concentrations in Street Dusts of Dhaka City, Bangladesh," Atmospheric Environment, Vol. 40, No. 21, 2006, pp. 3835-3844. doi:10.1016/j.atmosenv.2006.03.004

[2] S. Tokalioglu and S. Kartal, "Multivariate Analysis of the Data and Speciation of Heavy Metals in Street Dust Samples from the Organized Industrial District in Kayseri (Turkey)," Atmospheric Environment, Vol. 40, No. 16, 2006, pp. 2797-2805.

doi:10.1016/j.atmosenv.2006.01.019

[3] T. Bhattacharya, S. Chakraborty, B. Fadadu and P. Bhattacharya, "Heavy Metal Concentrations in Street and Leaf Deposited Dust in Anand City, India," Research Journal of Chemical Sciences, Vol. 1, No. 5, 2011, pp. 61-66.

[4] A. Chaterjee and R. N. Banerjee, "Determination of Lead and Other Metals in a Residential Area of Greater Calcutta," The Science of the Total Environment, Vol. 227, No. 2-3, 1999, pp. 175-185. doi:10.1016/S0048-9697(99)00026-1

[5] A. D. K. Banerjee, "Heavy Metal Levels and Solid Phase Speciation in Street Dusts of Delhi, India," Environmental Pollution, Vol. 123, No. 1, 2003, pp. 95-105. doi:10.1016/S0269-7491(02)00337-8

[6] Q. M. Jaradat and K. A. Momani, "Contamination of Roadside Soil, Plants, and Air with Heavy Metals in Jordan, A Comparative Study," Turkish Journal of Chemistry, Vol. 23, 1999, pp. 209-220.

[7] M. L. Jackson, "Soil Chemical Analysis," Y. Eagle Wood Cliff, New York, 1958, p. 498.

[8] Y. Faiz, M. Tufail, M. T. Javed, M. M. Chaudhry and N. Siddique, "Road Dust Pollution of $\mathrm{Cd}, \mathrm{Cu}, \mathrm{Ni}, \mathrm{Pb}$ and $\mathrm{Zn}$ along Islamabad Expressway, Pakistan," Microchemical Journal, Vol. 92, No. 2, 2009, pp. 186-192. doi:10.1016/j.microc.2009.03.009

[9] O. Al-Khashman, "Determination of Metal Accumulation in Deposited Street Dusts in Amman, Jordan," Environmental Geochemistry and Health, Vol. 29, No. 1, 2007, pp. 1-10. doi:10.1007/s10653-006-9067-8

[10] S. Jamil, P. C. Abhilash, A. Singh, N. Singh and H. M. Behl, "Fly Ash Trapping and Metal Accumulating Capacity of Plants Implication for Green Belt around Thermal Power Plants," Landscape and Urban Planning, Vol. 92, No. 2, 2009, pp. 136-147. doi:10.1016/j.landurbplan.2009.04.002

[11] E. De-Miguel, J. E. Llamas, E. Chacon and L. F. Mazadiego, "Sources and Pathways of Trace Elements in Urban Environments a Multi Elemental Qualitative Approach," The Science of the Total Environment, Vol. 235, No. 1-3, 1990, pp. 355-357.
[12] X. Li and L. M. Shuman, "Heavy Metal Movement in Metal Contaminated Soil Profiles," Soil Science, Vol. 161, No. 10, 1996, pp. 656-666. doi:10.1097/00010694-199610000-00003

[13] W. Fabis, "Schadstoftbelastung von Böden-Auswirkurgen auf Böden-und wasserqalitat AllgFarstzeitsehr," BLV Verlaggesellshaft, Munich, 1987, pp. 128-131.

[14] M. Yazdi and N. Behzad, "Heavy Metal Contamination and Distribution in the Parks City of Islam Shahr, SW Tehran, Iran," The Open Environmental Pollution \& Toxicology Journal, Vol. 1, 2009, pp. 49-53.

[15] A. J. Alhassan, M. S. Sule, M. K. Atiku, A. M. Wudil, M. A. Dangambo, J. A. Mashi and N. A. Ibrahim, "Study of Correlation between Heavy Metal Concentration, Street Dust and Level of Traffic in Major Roads of Kano Metropolis, Nigeria," Nigerian Journal of Basic and Applied Science, Vol. 20, No. 2, 2012, pp. 161-168.

[16] D. Y. Shinggu, V. O. Ogugbuaja, J. T. Barminas and I. Toma, "Analysis of Street Dust for Heavy Metal Pollutants in Mubi, Adamawa State, Nigeria," International Journal of Physical Sciences, Vol. 2, No. 11, 2007, pp. 290 293.

[17] H. Yongming, D. Peixuan, C. Junji and E. Posmentier, "Multivariate Analysis of Heavy Metal Contamination in Urban Dusts in Xi'an, Central China," Science of the Total Environment, Vol. 355, No. 1-3, 2006, pp. 176-186. doi:10.1016/j.scitotenv.2005.02.026

[18] A. Addo, E. O. Darko, C. Gordon, B. J. B. Nyarko and J. K. Gbadago, "Heavy Metal Concentrations in Road Deposited Dust at Ketu-South District, Ghana," International Journal of Science and Technology, Vol. 2, No. 1, 2012, pp. 28-39.

[19] V. Divrikli, M. Soylak, L. Elic and M. Dogan, "Trace Heavy Metal Levels in Street Dust Samples from Yazgat City Center, Turkey," Proceeding of 5th Scientific Environmental Conference, Vol. 21, No. 2, 2003, pp. 351-361.

[20] S. Charlesworth, M. Everett, R. McCarthy, A. Ordóñez and E. De Miguel, “A Comparative Study of Heavy Metal Contamination and Distribution in Deposited Street Dust in a Large and a Small Urban Area: Birmingham and Coventry, West Midlands, UK," Environment International, Vol. 29, No. 5, 2003, pp. 563-573. doi:10.1016/S0160-4120(03)00015-1

[21] S. M. El-Shayep and M. R. D. Seaward, "Heavy Metal Content of Roadside Soils along Ring Road in Riyadh (Saudi Arabia)," Asian Journal of Chemistry, Vol. 13, No. 2, 2001, pp. 407-423.

[22] S. Basha, J. Jhala, R. Thorat, S. Goel, R. Trivedi, K. Shah, G. Menon, P. Gaur, K. H. Mody and B. Jha, "Assessment of Heavy Metal Content in Suspended Particulate Matter of Coastal Industrial Town, Mithapur, Gujarat, India," Atmospheric Research, Vol. 97, No. 1-2, 2010, pp. 257-265.

[23] M. N. Ambulkar, N. L. Chutke, A. N. Aggarwal and A. N. Garg, "Multielemental Analysis of Ambient Air Dust Particulates from a Cement Factory by Neutron Activation," The Science of the Total Environment, Vol. 141, No. 1-3, 1994, pp. 93-101. doi:10.1016/0048-9697(94)90021-3

[24] K. K. Turekian and K. H. Wedepohl, "Distribution of the Elements in Some Major Units of the Earth's Crust," Bul- 
letin of Geological Society of America, Vol. 72, No. 2, 1961, pp. 175-192.

[25] Agency for Toxic Substances and Disease Registry, "Toxi- cological Profile for Chromium," US Department of Health and Human Service public Health Service, Atlanta, 2000. 